\title{
Quality Function Deployment Applied On Pvc Plumbing And Cast Iron Plumbing
}

\author{
Avadhesh Singh Gurjar ${ }^{1}$, Dr. M.K Trivedi ${ }^{2}$ \\ ${ }^{I}$ (Research Scholar, Department of civil engineering, MITS Gwalior (m.p.), India 474005) \\ ${ }^{2}$ (Professor, Department of civil engineering, MITS Gwalior (m.p.), India 474005)
}

\begin{abstract}
QFD is a methodology, which establishes a relationship between product descriptor \& customer expectation. It is also determine products sale ability and carryout it to a high liable during the process. In this study, QFD methodology was implement in the plumbing services such as PVC plumbing and cast iron plumbing. This study is an effort to try to develop the awareness \& importance of plumbing services and its utilization in productive manner among the people. The aim of this study is to use the better plumbing services as per customer requirement, we observed some functional problem. In the first step which is developed by customer voice the relationship which is customer requirement and technical description is determine by QFD and finally calculation all item are evaluated.
\end{abstract}

Key words: building house of quality, Cast iron plumbing, PVC plumbing, QFD methodology.

\section{Introduction}

Implementation of the total quality management system at the Mitsubishi Shipyard in Kobe, Japan. In the late 1970s, Toyota further developed the QFD concept to a detailed process that has been used in many manufacturing industries. Sullivan 1986 Reported that Toyota auto body started using QFD in 1977. As a result, Toyota auto body introduced four new van-type vehicles between 1977 and 1984, which is a record time for such an accomplishment. Using 1977 as a base, Toyota reported a 20\% reduction in start-up costs on the launch of its new van in 1979, a $38 \%$ reduction in 1982, and a cumulative $61 \%$ reduction in 1984 . During this period, the product development cycle \& time to market! was reduced by one-third, and quality was improved because of the significant reduction in the number of engineering changes and retread incidents. QFD is a customer-driven design process. Its use is essential in product design . Sullivan defines QFD as an overall concept that provides a means of translating customer requirements into the appropriate technical requirements . Various applications within the literature can be grouped under three categories as: QFD implementations before the design stage; QFD implementations during the design stage and QFD implementations after the design stage .QFD was originally proposed, through collecting and analyzing the voice of the customer, for QFD's potential fields of applications. QFD is a useful tool for developing the requirements of new products, and its benefits are well documented .

\section{Benefits of QFD}

Customer Driven, Provides Documentation, Reduced Implementation time, Promotes Teamwork.

\section{Aim Of This Study Are As Follows}

1. To meet the need of customer requirement.

2. To make the plumbing services more effective.

\section{Pve Pipes \& Castiron Pipes}

Polyvinyl-Chloride (PVC) is a plastic product .PVC pipes are light in weight, rates for use under pressure, easy to install, low frictional loss, low on maintenance cost, and have low frictional loss. PVC pipes of different diameters have gained wider acceptance for water supply. Their light weight, low cost, easy installation, non corrosiveness, high tensile strength to withstand high fluid pressure make them ideal for number of purposes. cast iron mains in this country which continue to give satisfactory services even after a century of use. Due to its strength and corrosion resistance, C.I pipes can be used in soils and for water of slightly aggressive character. They are well suited for pressure mains and laterals where tapping are made for house connections. It is preferable to have coating inside and outside of the pipe.Cheap Labor \& Cast Iron Years ago, residential construction labor costs were insignificant. Time was not always an issue with respect to how long a particular task took to complete.

\section{Types Of Customer Information}

1. Solicited, Measurable, Routine :-Customer \& Market Surveys, Trade Trials

2. Unsolicited, Measurable, Routine :customer ailment, cause

3. Solicited, Subjective, Routine :-Focus Groups 
4. Solicited, Subjective, Haphazard :-confabs, independent, looks up

5. Unsolicited, Subjective, Haphazard :-pattern sellers, provider

\section{Case Study}

Here we have taken two different plumbing and study is done at Surya industry Malanpur Gwalior and Sumer Galaxy multistory building Gwalior and according to the detail of market survey that we can use the QFD methodology for obtaining the better plumbing out of two (Cast iron and PVC plumbing).QFD focus on customer expectation or requirement, with the voice of the customer which employed to translate customer expectation in terms of specific requirement and action in terms of technical characteristics.

\begin{tabular}{|c|c|c|c|c|c|c|c|c|}
\hline & & & IICA & $\mathrm{CR}$ & $\begin{array}{l}\text { N/ } \\
\text { DW }\end{array}$ & IIN F & $\mathrm{JRE}$ & \\
\hline & & $\overrightarrow{\widetilde{a}}$ & $\tilde{\tilde{\Omega}}$ & $\stackrel{2}{\Delta}$ & 芩 & $\stackrel{\vartheta}{a}$ & مै & जै \\
\hline & CR1 & $\mathrm{R}_{11}$ & $\mathrm{R}_{12}$ & $\mathrm{R}_{13}$ & $\mathrm{R}_{14}$ & $\mathrm{R}_{15}$ & $\mathrm{R}_{16}$ & $R_{17}$ \\
\hline & CR2 & $\mathrm{R}_{21}$ & $\mathrm{R}_{22}$ & $R_{23}$ & $\mathrm{R}_{24}$ & $\mathrm{R}_{25}$ & $\mathrm{R}_{26}$ & $\mathrm{R}_{27}$ \\
\hline$\sum_{i=1}^{Z}$ & CR3 & $\mathrm{R}_{31}$ & $R_{32}$ & $\mathrm{R}_{33}$ & $\mathrm{R}_{34}$ & $\mathrm{R}_{35}$ & $\mathrm{R}_{36}$ & $R_{37}$ \\
\hline 党 & CR4 & $\mathrm{R}_{41}$ & $\mathrm{R}_{42}$ & $\mathrm{R}_{43}$ & $\mathrm{R}_{44}$ & $\mathrm{R}_{45}$ & $\mathrm{R}_{46}$ & $\mathrm{R}_{47}$ \\
\hline 澪 & CR5 & $\mathrm{R}_{51}$ & $\mathrm{R}_{52}$ & $\mathrm{R}_{53}$ & $\mathrm{R}_{54}$ & $\mathrm{R}_{55}$ & $\mathrm{R}_{56}$ & $\mathrm{R}_{57}$ \\
\hline$\stackrel{0}{b}$ & CR6 & $\mathrm{R}_{61}$ & $\mathrm{R}_{62}$ & $\mathrm{R}_{63}$ & $\mathrm{R}_{64}$ & $\mathrm{R}_{65}$ & $\mathrm{R}_{66}$ & $\mathrm{R}_{67}$ \\
\hline & CR7 & $\mathrm{R}_{71}$ & $\mathrm{R}_{72}$ & $\mathrm{R}_{73}$ & $\mathrm{R}_{74}$ & $\mathrm{R}_{75}$ & $\mathrm{R}_{76}$ & $\mathrm{R}_{77}$ \\
\hline
\end{tabular}

Where the relation value is

$$
\begin{aligned}
& \mathrm{R}_{11}=\mathrm{CR} 1 \text { \& DR1, } \mathrm{R}_{21}=\mathrm{CR} 2 \text { \& DR1 } \\
& \mathrm{R}_{12}=\mathrm{CR} 1 \text { \& DR2, } \mathrm{R}_{22}=\mathrm{CR} 2 \text { \& DR2 } \\
& \mathrm{R}_{76}=\mathrm{CR} 7 \text { \& DR6, } \mathrm{R}_{77}=\mathrm{CR} 7 \& \mathrm{DR} 7
\end{aligned}
$$

Similar

\section{Prioritized Customer Requirements}

Customer rankings will determine the base for the requirements to be prioritized. Table 2 shows the prioritized customer requirements.

\section{Importance to Customer-}

It will be useful for prioritizing efforts and trade-off decisions where team may have different priorities which are as :

5.1 Focus Team Information (ranks relative importance to customer) Rank each customers requirement by assigning it a value- 10 the highest -1 the least importance.

\subsection{Focus on team states:}

a) Cost ranks 8 out of 10

b) Lightweight 7 out of 10

c) Aerodynamic Look, Finish \& Strength 5 out of 10

d) Durable 3 out of 10

e) Corrosion Resistant 2 out of 10

\section{Target Value-}

This is the column where the QFD Team decides if they want to keep their product unchanged and improve the product simultaneous, or make the product better then what the competition does. The value take 1 is least important and 5 is most important. 


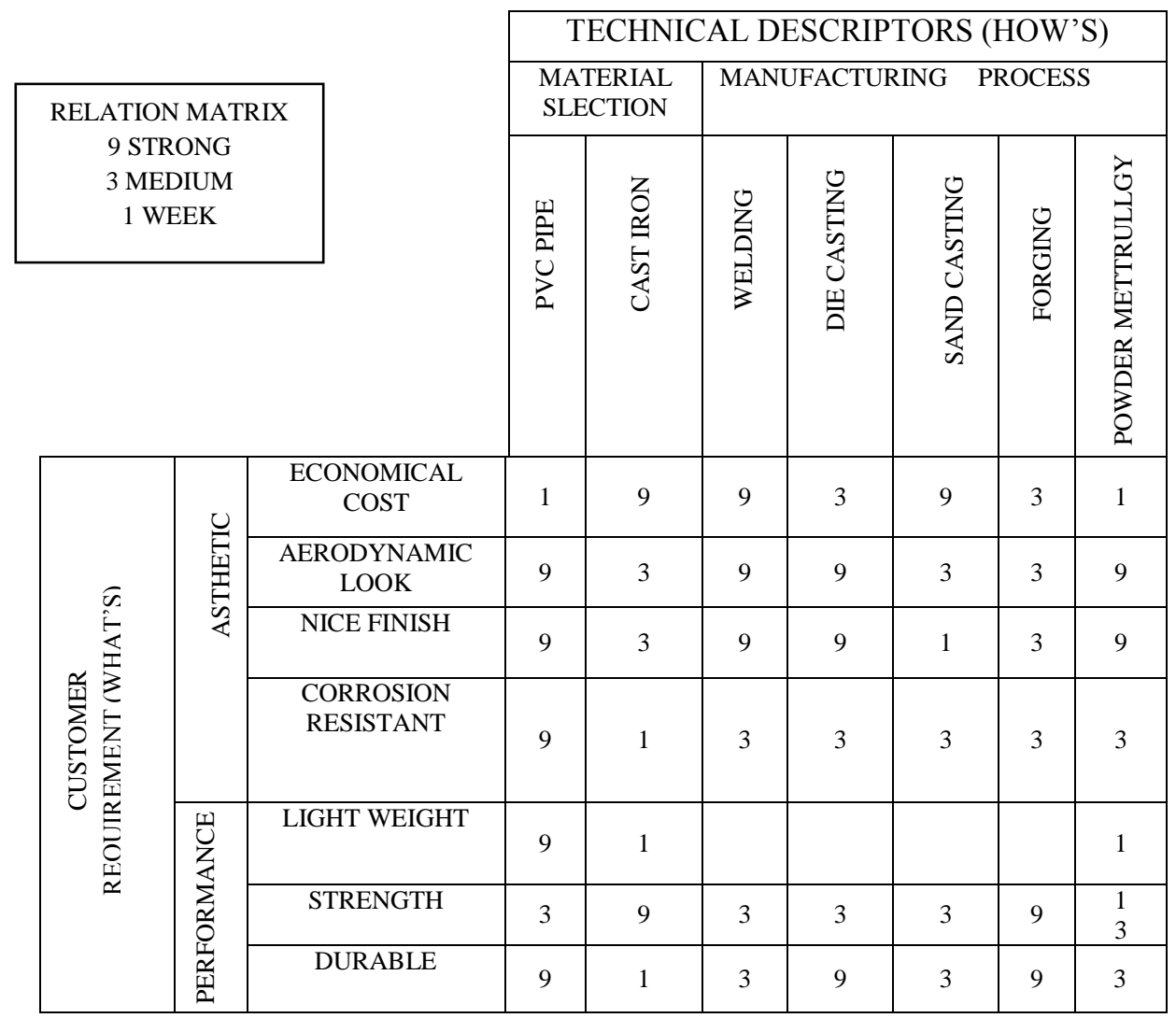

Table. 1- The Value Obtained By Market Survey And Describe D As Relation Ship Matrix Below Show

\begin{tabular}{|l|l|}
\hline Cost & +1 \\
\hline Look & \\
\hline Finish & \\
\hline corrosion resistant & \\
\hline Light Weight & +1 \\
\hline Strength & \\
\hline Durable & \\
\hline
\end{tabular}

\begin{tabular}{|l|l|l|}
\hline Our product & & Target value \\
\hline 3 & cost & 4 \\
\hline 4 & look & 4 \\
\hline 4 & Finish & 4 \\
\hline 4 & $\begin{array}{l}\text { Corrosion } \\
\text { resistant }\end{array}$ & 4 \\
\hline 3 & Light weight & 4 \\
\hline 3 & Strength & 3 \\
\hline 3 & Durable & 3 \\
\hline
\end{tabular}

\begin{tabular}{|ll|}
\hline Cost & 8 \\
Look & 5 \\
Finish & 5 \\
Corrosion Res. & 2 \\
Lightweight & 7 \\
Strength & 5 \\
Durable & 3 \\
\hline
\end{tabular}

\section{Scale-up Factor-}

The ratio of target value to the our product ranking given in the customer competitive assessment. Ratio of target value to the product rating given in the customer competitive assessment. In this case, Cost and Lightweight had a product rating of 3 and the target value is 4 so scale-up factor is 1.3 and 1 to show no further target value. 


\begin{tabular}{|l|l|}
\hline Cost & 1.3 \\
\hline Look & 1 \\
\hline Finish & 1 \\
\hline corrosion resistant & 1 \\
\hline $\begin{array}{l}\text { Light } \\
\text { Weight }\end{array}$ & 1.3 \\
\hline Strength & 1 \\
\hline Durable & 1 \\
\hline
\end{tabular}

\section{Sale-point-}

Customer Requirement will Sell Best Customer Requirement and any other of the customer requirement that will help in the sale of the product. Encourage the Best Customer Requirement and any other of the customer requirement that will help in the sale of the product. Sales Point is a value between 1.0 and 2.0 with 2.0 being the Highest.

In this case, lightweight is the strongest at 2. The cost and Aerodynamic look rank 1.5 and 1 as show do not factor in sale

\section{Absolute Weight -}

\begin{tabular}{|l|l|}
\hline Cost & 1.5 \\
\hline Look & 1.5 \\
\hline Finish & 1 \\
\hline $\begin{array}{l}\text { corrison } \\
\text { resistant }\end{array}$ & 1 \\
\hline Light Weight & 2 \\
\hline Strength & 1 \\
\hline Durable & 1 \\
\hline
\end{tabular}

After evaluate all the absolute weights, a percent and rank for each customer requirement can be determined. Absolute Weight $=($ Importance to the Customer $*$ Scale-Up factor $*$ Sales Point $)$ $(8 * 1.3 * 1.5=16)$

\begin{tabular}{|l|l|}
\hline Cost & 16 \\
\hline Look & 8 \\
\hline Finish & 5 \\
\hline corrosion resistant & 2 \\
\hline Light Weight & 18 \\
\hline Strength & 5 \\
\hline Durable & 3 \\
\hline
\end{tabular}

\section{Prioritized Technical Descriptors}

This is a block of rows in the foundation of the house corresponding to each technical descriptor. These moderate degree of technical difficulty, target value and absolute and relative weights. The QFD team identifies technical descriptors that are most needed to fulfill customers expectations and need improvement. Table 3 shows the prioritized technical descriptors.

Points to be Consider.

1. Team should consider: Available-technology, Technical-characteristics, Cost, Schedule, Supplier/subcontractor-capability, Manufacturing capabilities, Personnel qualifications

2. Degree of technical difficulty-:The objective of this step is to guide the design, objectively assesses progress.

Least Difficult $=1$ to Most Difficult $=10$

The degree of difficulty for welding is 7 and the degree of difficulty for Sand Casing is 3 because it is a much easier manufacturing process-

\begin{tabular}{|l|l|l|l|l|l|l|}
\hline P.v.c & Cast iron & Welding & Die casting & Sand casting & Forging & $\begin{array}{l}\text { Powder } \\
\text { metallurgy }\end{array}$ \\
\hline 6 & 9 & 7 & 4 & 3 & 6 & 9 \\
\hline
\end{tabular}

3. Target Value- This is a objective measure that defines values, must be obtained to achieve the technical descriptors. How much it takes to meet or exceed the customers expectations is answered by evaluating all the information entered into the House of Quality and selecting target values. 
Quality Function Deployment Applied On Pvc Plumbing And Cast Iron Plumbing

\begin{tabular}{|l|l|l|l|l|l|l|}
\hline P.v.c & Cast iron & Welding & Die casting & Sand casting & Forging & $\begin{array}{l}\text { Powder } \\
\text { metallurgy }\end{array}$ \\
\hline 5 & 5 & 4 & 5 & 0 & 0 & 0 \\
\hline
\end{tabular}

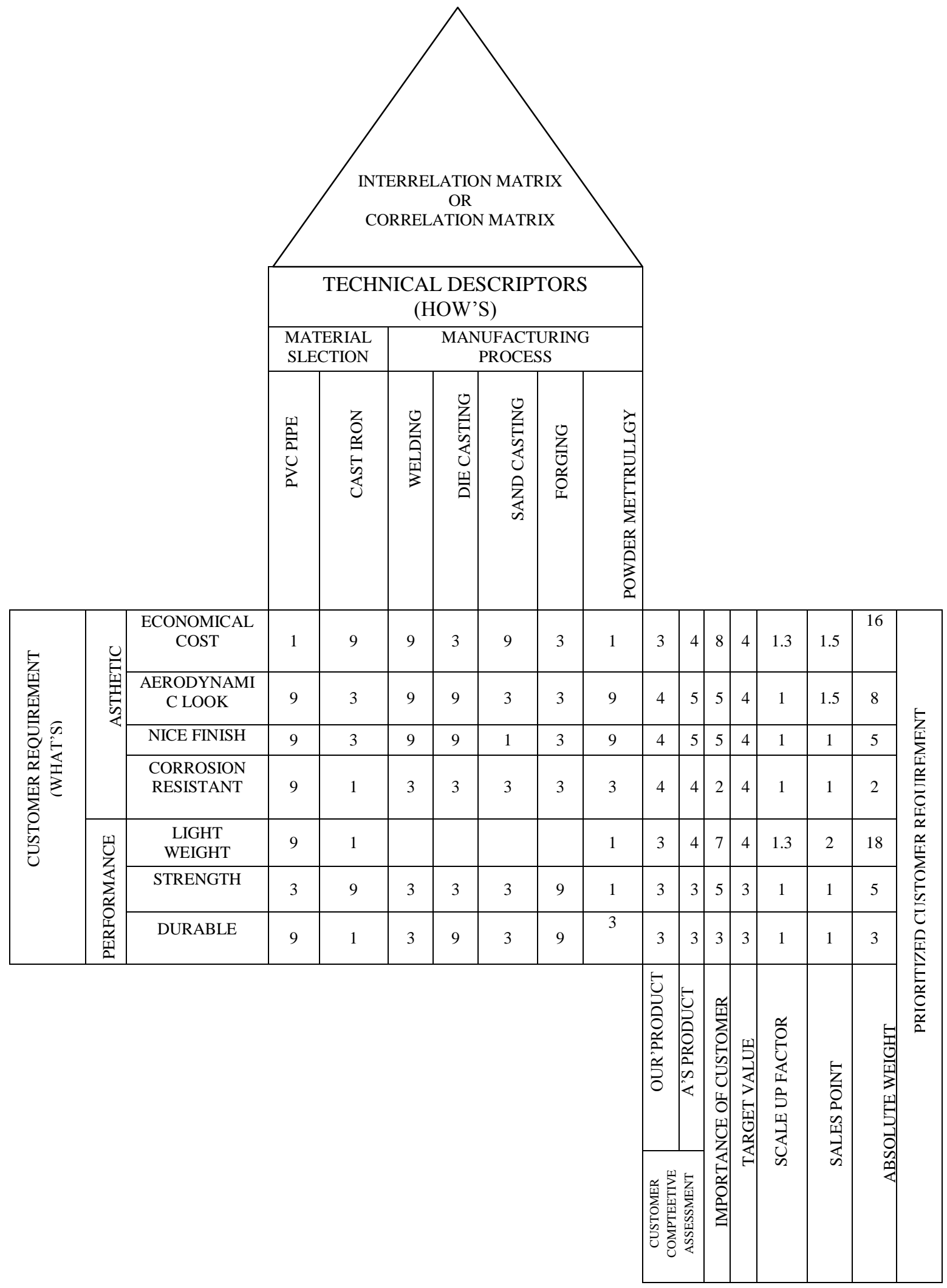

Table. 2-Prioritized Customer Requirement 


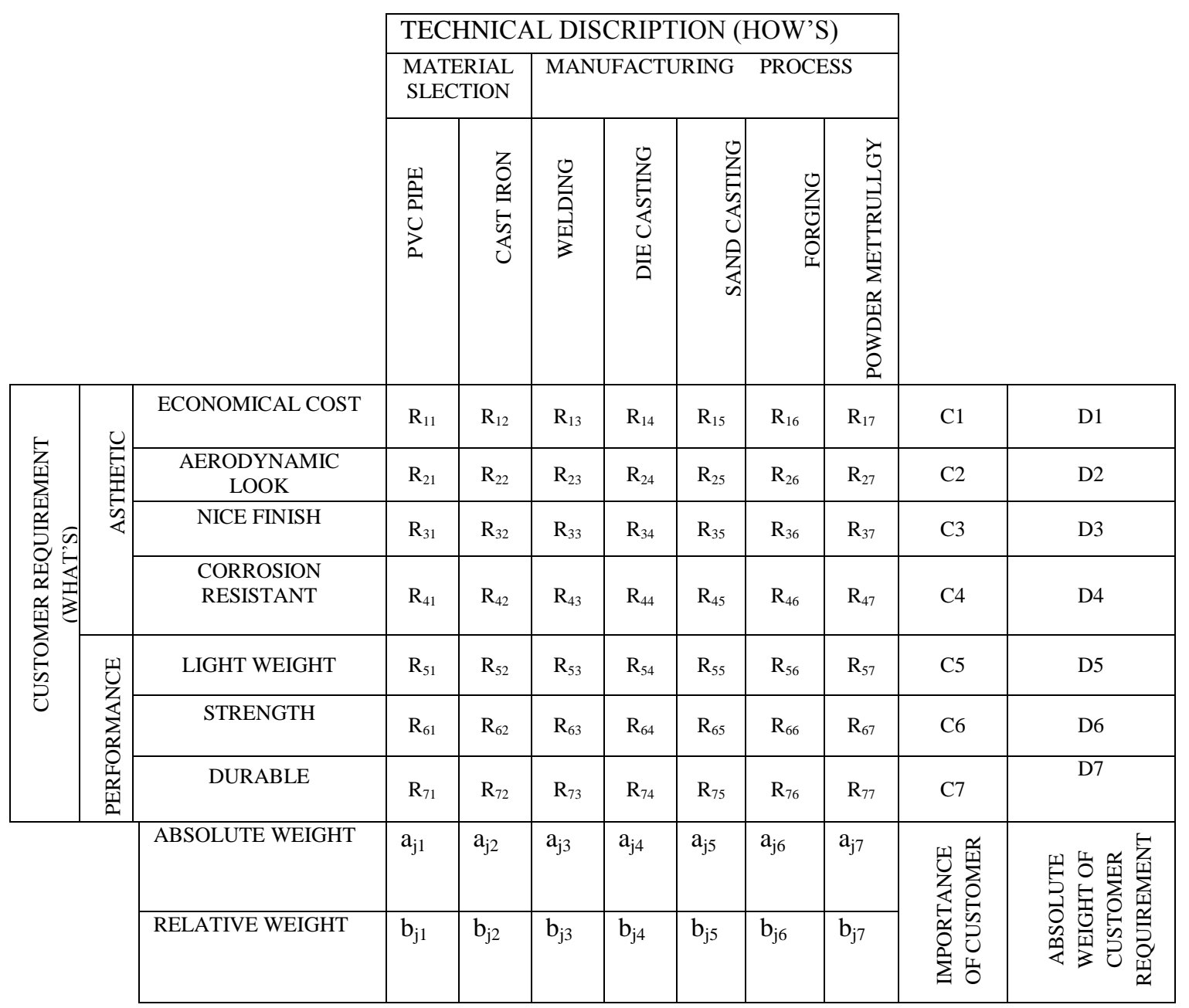

Table. 3- The value observed \& calculated then matrix are define

\section{Absolute Weight \& Percent-}

$$
a_{j}=\sum_{i=1}^{n} R_{i j} c_{i}
$$

Where- $a_{j}=$ row vector of absolute weights for the technical descriptor $(i=1, \ldots . \mathrm{m})$

$\mathrm{R}_{\mathrm{ij}}=$ weights assigned to the Relationship Matrix

$\mathrm{C}_{\mathrm{i}}=$ column vector of importance for the Customer requirement $\mathrm{m}=$ no. of technical descriptors

$\mathrm{n}=$ no. of customer requirement

$$
\begin{gathered}
\mathrm{a}_{\mathrm{j} 1}=\mathrm{R}_{11} * \mathrm{C} 1+\mathrm{R}_{21} * \mathrm{C} 2+\mathrm{R}_{31} * \mathrm{C} 3+\mathrm{R}_{41} * \mathrm{C} 4+\mathrm{R}_{51} * \mathrm{C} 5+\mathrm{R}_{61} * \mathrm{C} 6+\mathrm{R}_{71} * \mathrm{C} 7 \\
\mathrm{a}_{\mathrm{j} 1=} 1 * 8+9 * 5+9 * 5+9 * 2+9 * 7+3 * 5+9 * 3=221
\end{gathered}
$$

Similarly

$$
\begin{gathered}
\mathrm{a}_{\mathrm{j} 2}=\mathrm{R}_{12} * \mathrm{C} 1+\mathrm{R}_{22} * \mathrm{C} 2+\mathrm{R}_{32} * \mathrm{C} 3+\mathrm{R}_{42} * \mathrm{C} 4+\mathrm{R}_{52} * \mathrm{C} 5+\mathrm{R}_{62} * \mathrm{C} 6+\mathrm{R}_{72} * \mathrm{C} 7 \\
\mathrm{a}_{\mathrm{j} 2}=159 \\
\mathrm{a}_{\mathrm{j} 3}=\mathrm{R}_{13} * \mathrm{C} 1+\mathrm{R}_{23} * \mathrm{C} 2+\mathrm{R}_{33} * \mathrm{C} 3+\mathrm{R}_{43} * \mathrm{C} 4+\mathrm{R}_{53} * \mathrm{C} 5+\mathrm{R}_{63} * \mathrm{C} 6+\mathrm{R}_{73} * \mathrm{C} 7 \\
\mathrm{a}_{\mathrm{j} 3}=192 \\
\mathrm{a}_{\mathrm{j} 4}=\mathrm{R}_{14} * \mathrm{C} 1+\mathrm{R}_{24} * \mathrm{C} 2+\mathrm{R}_{34} * \mathrm{C} 3+\mathrm{R}_{44} * \mathrm{C} 4+\mathrm{R}_{54} * \mathrm{C} 5+\mathrm{R}_{64} * \mathrm{C} 6+\mathrm{R}_{74} * \mathrm{C} 7 \\
\mathrm{a}_{\mathrm{j} 4}=132 \\
\mathrm{a}_{\mathrm{j} 5}=\mathrm{R}_{15} * \mathrm{C} 1+\mathrm{R}_{25} * \mathrm{C} 2+\mathrm{R}_{35} * \mathrm{C} 3+\mathrm{R}_{45} * \mathrm{C} 4+\mathrm{R}_{55} * \mathrm{C} 5+\mathrm{R}_{65} * \mathrm{C} 6+\mathrm{R}_{75} * \mathrm{C} 7 \\
\mathrm{a}_{\mathrm{j} 5}=122
\end{gathered}
$$




$$
\begin{gathered}
\mathrm{a}_{\mathrm{j} 6}=\mathrm{R}_{16} * \mathrm{C} 1+\mathrm{R}_{26} * \mathrm{C} 2+\mathrm{R}_{36} * \mathrm{C} 3+\mathrm{R}_{46} * \mathrm{C} 4+\mathrm{R}_{56} * \mathrm{C} 5+\mathrm{R}_{66} * \mathrm{C} 6+\mathrm{R}_{76} * \mathrm{C} 7 \\
\mathrm{a}_{\mathrm{j} 6}=132 \\
\mathrm{a}_{\mathrm{j} 7}=\mathrm{R}_{17} * \mathrm{C} 1+\mathrm{R}_{27} * \mathrm{C} 2+\mathrm{R}_{37} * \mathrm{C} 3+\mathrm{R}_{47} * \mathrm{C} 4+\mathrm{R}_{57} * \mathrm{C} 5+\mathrm{R}_{67} * \mathrm{C} 6+\mathrm{R}_{77} * \mathrm{C} 7 \\
\mathrm{a}_{\mathrm{j} 7}=125
\end{gathered}
$$

\section{Relative Weight \& Percent-}

$$
b_{j}=\sum_{i=1}^{n} R_{i j} d_{i}
$$

Where- $b_{j}=$ row vector of relative weights for the technical descriptor $(j=1, \ldots \ldots . . m)$

$\mathrm{R}_{\mathrm{ij}}=$ weights assigned to the Relationship Matrix

$\mathrm{d}_{\mathrm{i}}=$ column vector of absolute weights for the Customer requirement $(\mathrm{i}=1, \ldots \ldots \mathrm{n})$

$\mathrm{m}=$ no. of technical descriptors

$\mathrm{n}=$ no. of customer requirement

$$
\begin{gathered}
b_{j 1}=R_{11} * D 1+R_{21} * D 2+R_{31} * D 3+R_{41} * D 4+R_{51} * D 5+R_{61} * D 6+R_{71} * D 7 \\
b_{j 1}=1 * 16+9 * 8+9 * 5+9 * 2+9 * 18+3 * 5+9 * 3=355
\end{gathered}
$$

Similarly,

$$
\begin{gathered}
b_{j 2}=R_{12} * D 1+R_{22} * D 2+R_{32} * D 3+R_{42} * D 4+R_{52} * D 5+R_{62} * D 6+R_{72} * D 7 \\
b_{j 2}=251 \\
b_{j 3}=R_{13} * D 1+R_{23} * D 2+R_{33} * D 3+R_{43} * D 4+R_{53} * D 5+R_{63} * D 6+R_{73} * D 7 \\
b_{j 3}=291 \\
b_{j 4}=R_{14} * D 1+R_{24} * D 2+R_{34} * D 3+R_{44} * D 4+R_{54} * D 5+R_{64} * D 6+R_{74} * D 7 \\
b_{j 4}=213 \\
b_{j 5}=R_{15} * D 1+R_{25} * D 2+R_{35} * D 3+R_{45} * D 4+R_{55} * D 5+R_{65} * D 6+R_{75} * D 7 \\
b_{j 5}=203 \\
b_{j 6}=R_{16} * D 1+R_{26} * D 2+R_{36} * D 3+R_{46} * D 4+R_{56} * D 5+R_{66} * D 6+R_{76} * D 7 \\
b_{j 6}=165 \\
b_{j 7}=R_{17} * D 1+R_{27} * D 2+R_{37} * D 3+R_{47} * D 4+R_{57} * D 5+R_{67} * D 6+R_{77} * D 7 \\
b_{j 7}=171
\end{gathered}
$$

\section{Interrelation Matrix Between Hows}

The roof of house of quality called the correlation matrix ,is used to identify any interrelation between each of the technical descriptors .The correlation matrix is a triangular table attached to the technical descriptors, as shown in table 5 below .symbol are used to describe the strength of the interrelationship.

\section{Results}

In plumbing we have applied QFD on different pipes such as p.v.c. or cast iron. In this study, it is formed that the absolute weight or relative weight of p.v.c. Pipe is much higher than the other pipes. There for it is more suitable for the procurement and as shown in the table 4 below

\begin{tabular}{|l|l|l|}
\hline & Absolute weight & Relative weight \\
\hline P.v.c. & 221 & 355 \\
\hline Cast iron & 159 & 251 \\
\hline Welding & 192 & 291 \\
\hline Die casting & 162 & 213 \\
\hline Sand casting & 122 & 203 \\
\hline Forging & 132 & 165 \\
\hline Powder metallurgy & 125 & 171 \\
\hline
\end{tabular}

Table. 4- Absolute weight vs. relative weight 


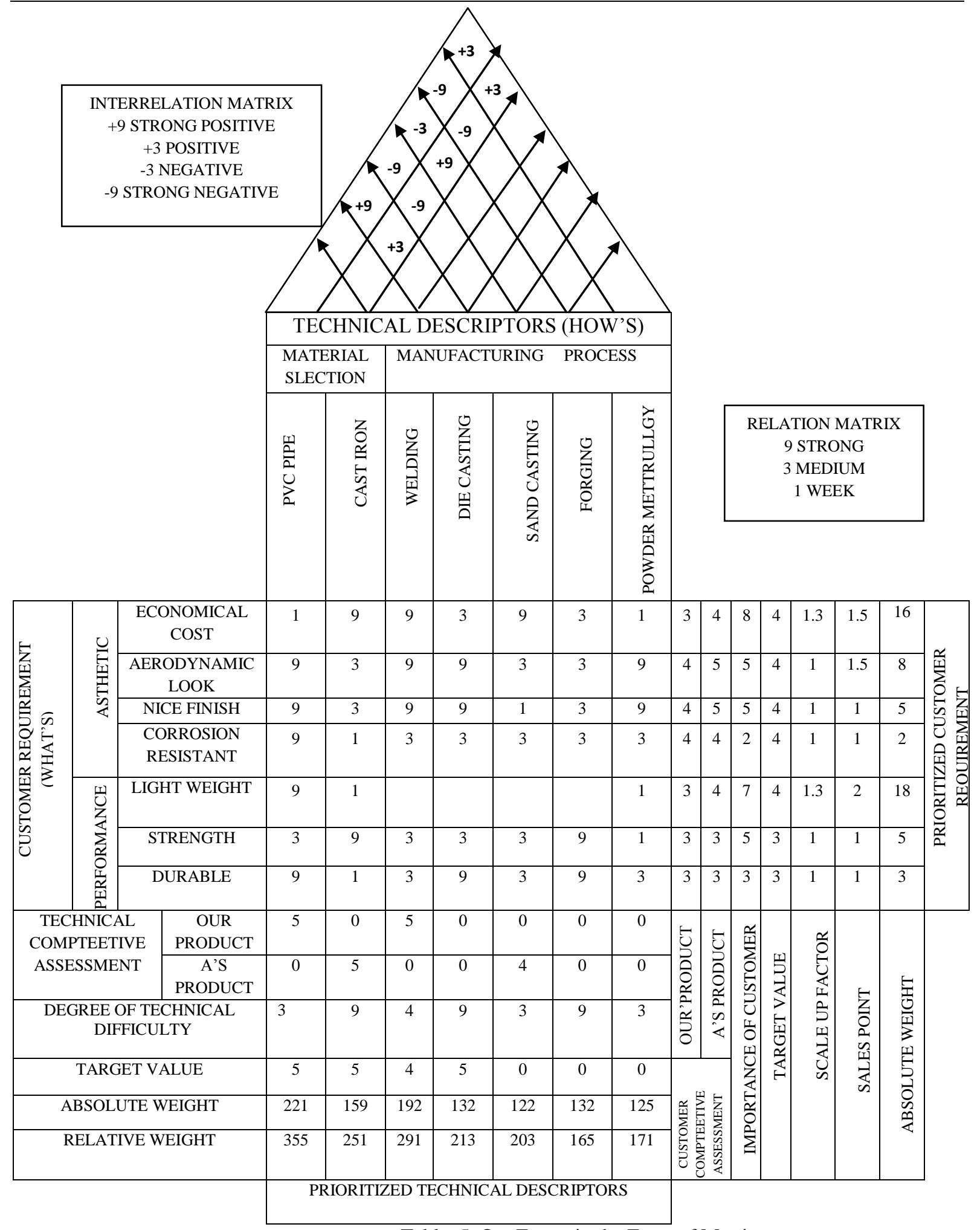

Table. 5-Out Frame in the Form of Matrix

IX. Conclusion

In this work it is observed that QFD plays a deciding role for the relation of plumbing materials where customer and design requirement are properly taken care. PVC plumbing is the best in respect corrosion, welding , aesthetic appearance ,durability easy to operating and maintenance it is formed that the plumbing cast iron material is three time costlier than the plumbing by p.v.c. Material, which is very high and uneconomical .PVC material is anti corrosion which is very good for normal liquid flow . 


\section{References}

[1] Ahmed, S. M., and Kangari R. (1996). "Quality function deployment in building construction." Proc., 8th Symp. on Quality Function Deployment, GOAL/QPC, Novi, Mich., 209-220.

[2] Akao, Y. (1990). "History of quality function deployment in Japan." The best on quality, IAQ Book Ser., International Academy for Quality, Frankfurt, Germany, Vol. 3, 183-196.

[3] Arditi, D. and Lee, D.E. (2003). Assessing the corporate service quality performance of designbuild contractors using quality function deployment, Construction Management and Economics 21: 175-185.

[4] Besterfield, D.H., Besterfield-Michna, C., Besterfield G. and Besterfield-Sacre, M. (1995). Total Quality Management, Prentice Hall, New Jersey.

[5] Chan, L.K. and Wu, M.L. (2003). Quality Function Deployment: A Comprehensive Review of Its Concepts and Methods .Quality Engineering 15(1), pp. 23-35.

[6] Chan, L.K. and Wu, M.L. (2002). Quality function deployment: A literature review. European Journal of Operational Research, 143, pp.463-497.

[7] Cohen, L. (1995). Quality Function Deployment: How to Make QFD Work for You, 1st Edition. Prentice Hall, New Jersey. 